\title{
Implementasi Repository E-Pappers Koran Pada Harian Umum Lampung Post (PT.Masa Kini Mandiri)
}

\author{
${ }^{1}$ Jimi Ali Baba, ${ }^{2}$ Agung Harikresna Hayattdi \\ Sekolah Tinggi Manajemen Informatika dan Komputer (STMIK) Pringsewu \\ J1. Wismarini No.09 Pringsewu Lampung \\ E-mail : jimialibaba@gmail.com ${ }^{1}$, hyattdi@gmail.com²
}

\begin{abstract}
Abstrak - Media online saat ini sudah mulai bertaburan di tambah dengan kondisi covid-19 yang tak kunjung menghilang membuat sebagian dari kita terpaku di depan gadget untuk sekedar mengakses media online. di tengah terpaan dirupsi teknologi lampung post khususnya di bagian kesekretariatan mulai berbenah dalam mengatasi papper atau koran cetak yang semakin bertambah banyak untuk di koleksi. Untuk mengoptimasi dalam implementasi sistem repository ini penelitian kali ini menggunakan aplikasi yang berjalan di browser, manfaatkan Server Linux dan aplikasi Nginx serta Wordpress dalam pembuatan aplikasi tersebut.
\end{abstract}

Kata Kunci : Repository, Nginx, Wordpress

\section{Pendahuluan}

Disrupsi teknologi informasi semaking deras menerpa sehingga tidak dapat kita hindari unutk mulai menyatu bersama teknologi iformasi tersebut, semakin banyaknya teknologi yang berkembang semakin mudah pula kita untuk mengimplementasikannya. Semenjak mudahnya informasi yang hadir pada saat ini dan kemudahaan akan teknologi yang di gunakan sehingga suatu organisasi dapat dengan mudah untuk mengorganisir data-data yang akan di perlukan. Dengan pesatnya perkembangan teknologi itu pula lah penelitian tentang repository e-pappers koran ini juga dapat di lakukan di dalam organisasi yang bergerak di bidang media cetak dan elektronik. Repository yang dulu hanya kupulan paket-paket atau library-library kecil kini mulai merambah ke berbagai sektor, tak hanya di dunia pendidikan repository saat ini sangat di butuhkan pula di berbagai organisasi.

Berkembang menjadi media masa yang terkonvergensi dengan sistem informasi yang berkembang pada saat ini. Membuat PT. Masa Kini Mandiri (Lampung Post) bergerak maju untuk menerima tantangan baru di dunia teknologi yang sangat berkembang pesat[1]. Di tengah gempuran teknologi informasi membuat kita di manjakan dengan berbagai informasi yang dapat dengan mudah kita ikuti atau dapatkan, dengan kemudahan itu pula lah di bagian kesekretariatan khususnya di lampungpost mulai berinisiasi untuk mengembangkan sistem informasi repository e-ppapers koran unutk memudahkan bagian kesekretariatan mendokumentasikan atau menyimpan hasil koran yang sudah di cetak ke dalam bentuk digital.

Inisiasi repository e-papper koran ini muncul di karenakan kesukaran pada bagian kesekretariatan dalam pendokumentasian dan tak jarang pula bagian bagian terkain apabila membutuhkan dokumen koran tersebut selalu menghadapi kendalah dalam pencarian karenan kondisi dokumentasi korang yang belum terdigitalisasi. Untuk memudahkan di bagian kesekretariatan dan bagian bagian lain apabila menginginkan dokemen koran yang sudah tercetak dapat dengan mudah mencari di dalam sistem repository e-papper koran untuk mendapatkannya. Pembaruan sistem repository berbasis web dapat memberikan kemudahan kepada petugas dalam mengelola sistem informasi dokumentasi[2]. Penelitian yang telah dilakukan terdapat beberapa masalah dalam hal ini:

1. Pengelolaan dokumen koran yang sudah tercetak sulit untuk di lakukan penyimpanannya dan membutuhkan ruangan untuk menyimpannya.

2. Bagian terkain yang ingin mendapatkan dokumen tekendalah dalam hal tersebut

3. Banyaknya dokumen koren hasil cetak yang menumpuk sehingga banyak yang tercecer atau hilang pada saat korang tersebut di butuhkan.

\section{Tinjauan Pustaka}

Koran berasal dari bahasa Belanda: Krant, dari bahasa Perancis disebut courant atau surat kabar adalah suatu penerbitan yang ringan dan mudah dibuang, biasanya dicetak pada kertas berbiaya rendah yang disebut kertas koran, yang berisi berita-berita terkini dalam berbagai topik. Topiknya bisa berupa even politik, kriminalitas, olahraga, tajuk rencana, cuaca. Surat kabar juga biasa berisi kartun, TTS dan hiburan lainnya. Ada juga surat kabar yang dikembangkan untuk bidang-bidang tertentu, misalnya berita untuk industri tertentu, penggemar olahraga tertentu, penggemar seni atau partisipan kegiatan tertentu.

Jenis surat kabar umum biasanya diterbitkan setiap hari, kecuali pada hari-hari libur. Surat kabar sore juga umum di beberapa negara. Selain itu, juga terdapat surat kabar mingguan yang biasanya lebih kecil dan kurang 
prestisius dibandingkan dengan surat kabar harian dan isinya biasanya lebih bersifat hiburan. Kebanyakan negara mempunyai setidaknya satu surat kabar nasional yang terbit di seluruh bagian negara[3].

Repositori adalah tempat penyimpanan, dan dalam konteks kepustakawanan repository adalah suatu tempat di mana dokumen, informasi atau data disimpan, dipelihara dan digunakan[4]. Software Repository Untuk menjalankan Repositori Institusi diperlukan software atau perangkat lunak[5]. Pilihan perangkat lunak tergantung kebutuhan dan ada 3 jalur yang bisa ditempuh yaitu membangun sendiri, membeli produk yang sudah jadi dan memanfaatkan aplikasi opensource. Membangun sendiri berarti harus mempunyai staf yang mempunyai pengetahuan tentang pemrograman atau menyewa tenaga outsourcing dan mempunyai tenaga pustakawan yang bertindak sebagai analis system. Sementara itu bisa juga menggunakan paket perangkat lunak (software) yang tersedia gratis untuk menjalankan repositori yaitu: Dspace (dikembangkan MIT US), Eprints (University of Southampton UK), Fedora, Inveno, Sobek CM dan GDL KMRG-ITB. Pemilihan penggunaan perangkat lunak yang tepat akan sangat membantu mempermudah pustakawan untuk mengorganisasi informasi muatan lokal yang akan di publish atau diterbitkan[6].

WWW atau World Wide Web maupun Web adalah sebuah sistem yang saling terkait dalam sebuah dokumen berformat hypertext yang berisi beragam informasi, baik tulisan, gambar, suara, video, dna informasi multimedia lainnya dan dapat di akses melalui sebuah perangkat yang disebut web browser[7]. Sebuah website terdiri dari halaman-halaman yang dipublikasikan oleh web server. Salah satu atau beberapa elemen-elemen ini harus ada dalam sebuah halaman agar halaman web tersebut memiliki maksud dan arti tertentu. Elemenelemen tersebut adalah segala sesuatu yang bisa kita lihat maupun dengar dalam sebuah halaman website diantaranya teks, gambar, hyperlink, audio dan video[8].

Server web adalah server yang melayani permintaan klien terhadap halaman web, ISS (Internet Information Server), dan Xitami merupakan contoh perangkap lunak web server[9]. Server Web adalah komputer yang dikhususkan untuk menaruh data website, hanya saja dalam hal ini server harus 24 jam online, jika tidak maka data tak bisa diakses oleh pengunjung website[10]. Penggunaan Web Server pada penelitian kali ini memanfaatkan aplikasi Nginx sebagai web server[11].

Wordpress adalah sebuah platform website yang bersifat open scource dan sangat popular. Wordpress digunakan sebagai mesin blog ataupun untuk platform yang bisa dimanfaatkan untuk membuat website multi fungsi dengan memanfaatkan berbagai plugins[8].

\section{Metode Penelitian}

Metode penelitian yang digunakan dalam kajian ini adalah pendekatan kualitatif dengan metode deskriptif. Lokasi penelitian ini adalah di PT. Masa Kini Mandiri, website:http://lampungpost.id/. Teknik pengumpulan data pada penelitian ini menggunakan teknik wawancara, observasi dan dokumentasi. Wawancara dilakukan pada Bagian Kesekretariatan redaksi lampungpost atau PT. Masa Kini Mandiri. Observasi dilakukan dengan menganalisis penggunaan sistem lama sehinggal terbentuklah konsep baru untuk mengembangkan aplikasi soal Repositori E-papper koran pada sekretariat redaksi. Dokumentasi dilakukan dengan mengumpulkan dan menganalisis dokumen yang berkaitan dalam pengelolaan Repositori E-papper Koran[12].

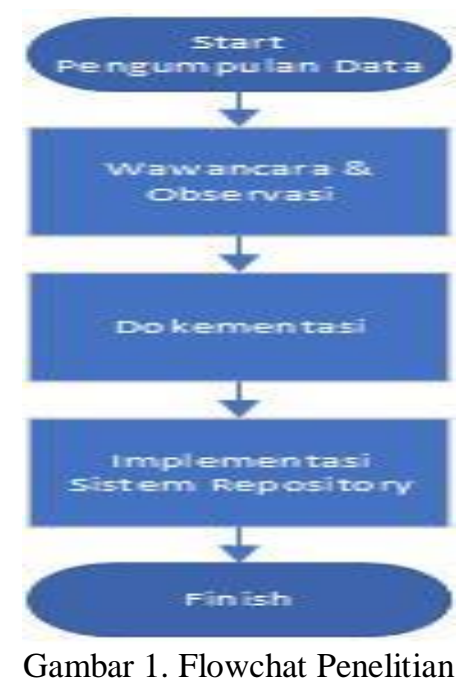




\section{Hasil Dan Pembahasan}

\subsection{Analisa Sistem}

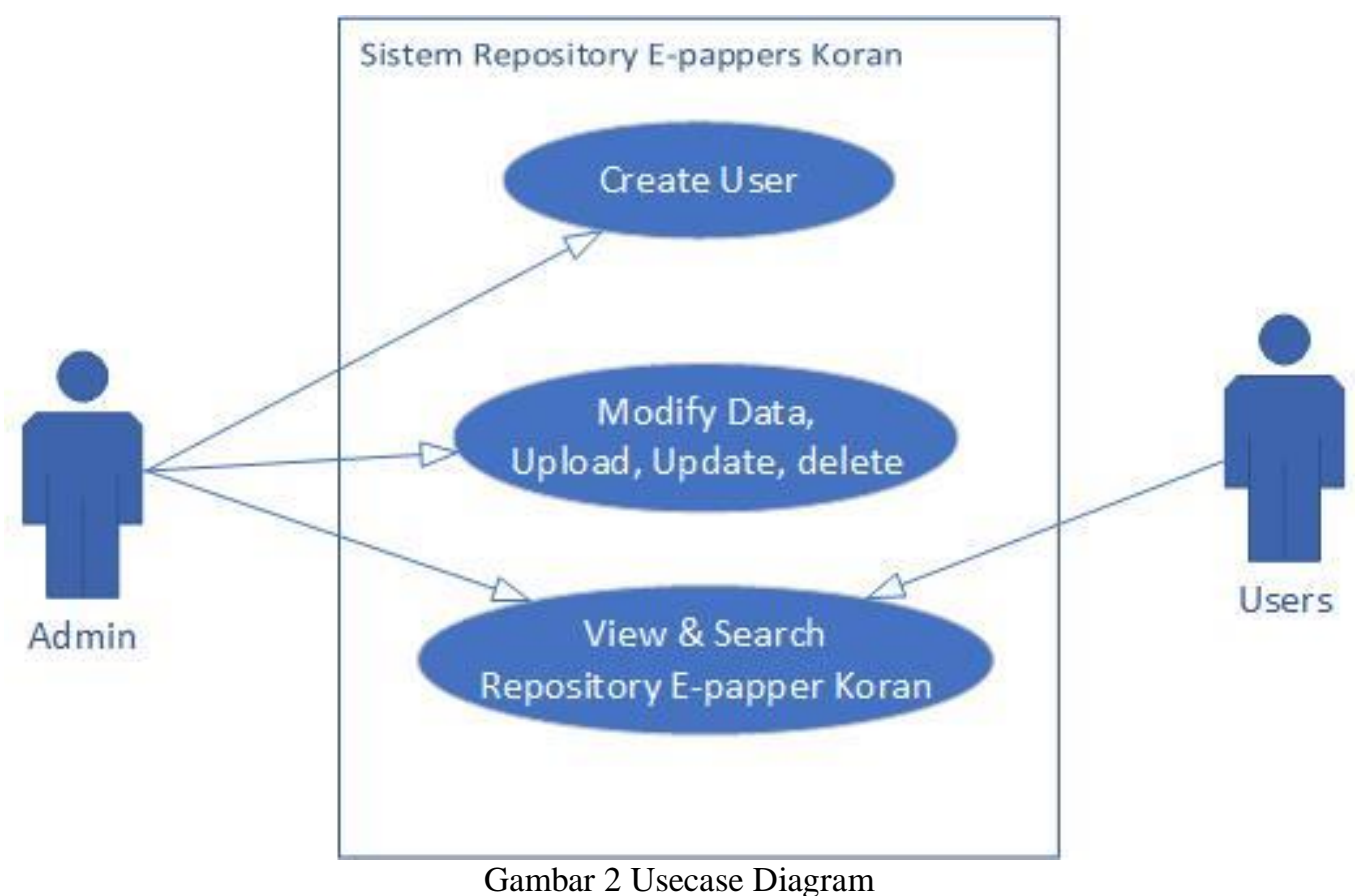

Dari gambar 2 tersebut terlihat usecase diagram antara aktor seperti Admin dan Users, dari kedua aktor tersebut admin sangat berperan penting dalam sistem repository e-pappers koran dan untuk users hanya dapat melihat dan mencari di dalam sistem tersebut.

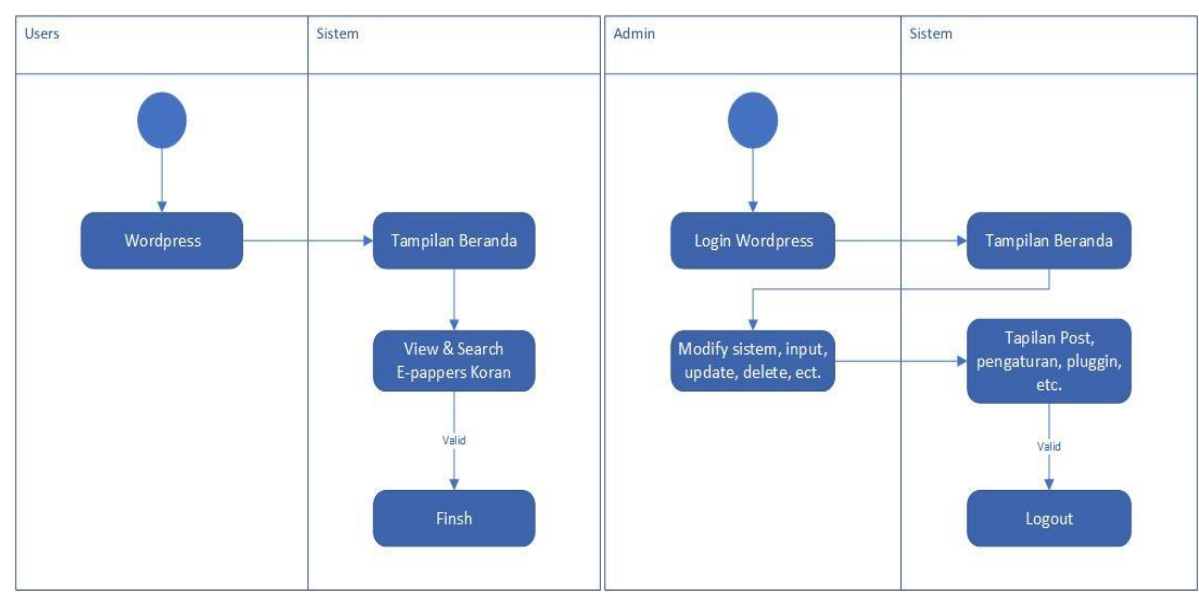

Gambar 3 Diagram Activity

Dari gambar 3 diatas terlihat diagram activity antara aktor admin dan aktor user, dari kedua aktor tersebut terlihat masing-masing fungsi di dalam sistem repository e-papper tersebut. 


\subsection{Implementasi system}

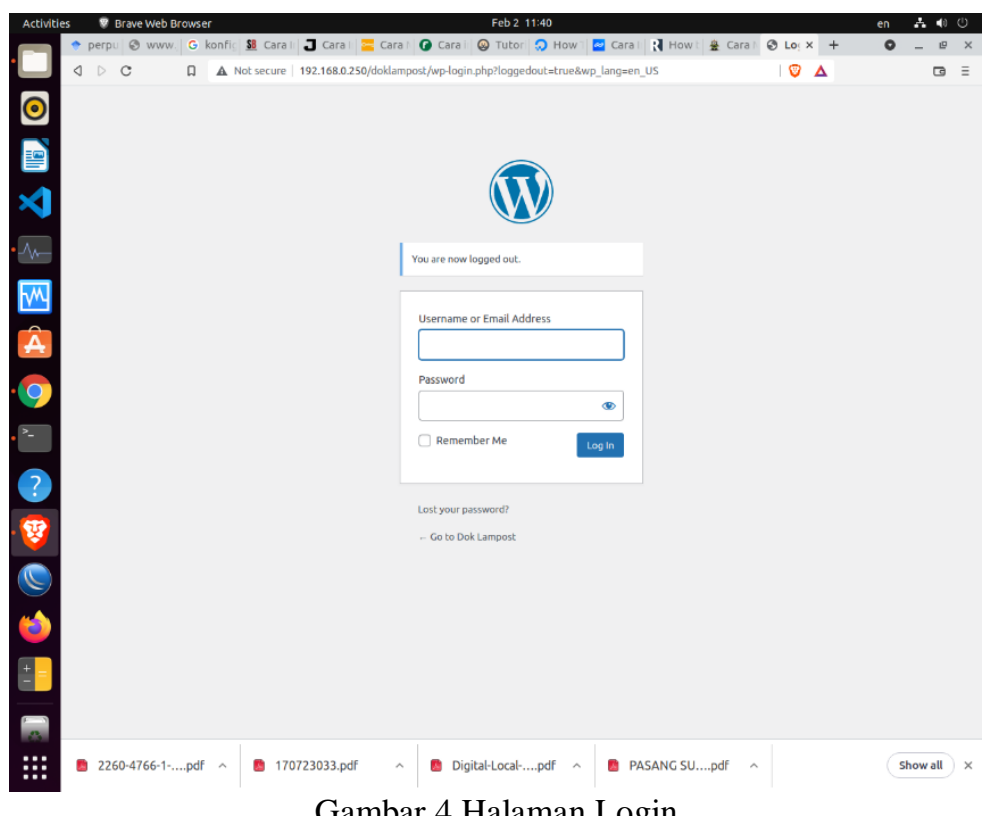

Gambar 4 Halaman Login

Dari gambar 4 terlihat tampilan login pada wordpres sistem repository e-pappers koran. Login di lakukan dari aktivitas admin dalam mengolah data di dalam sistem.

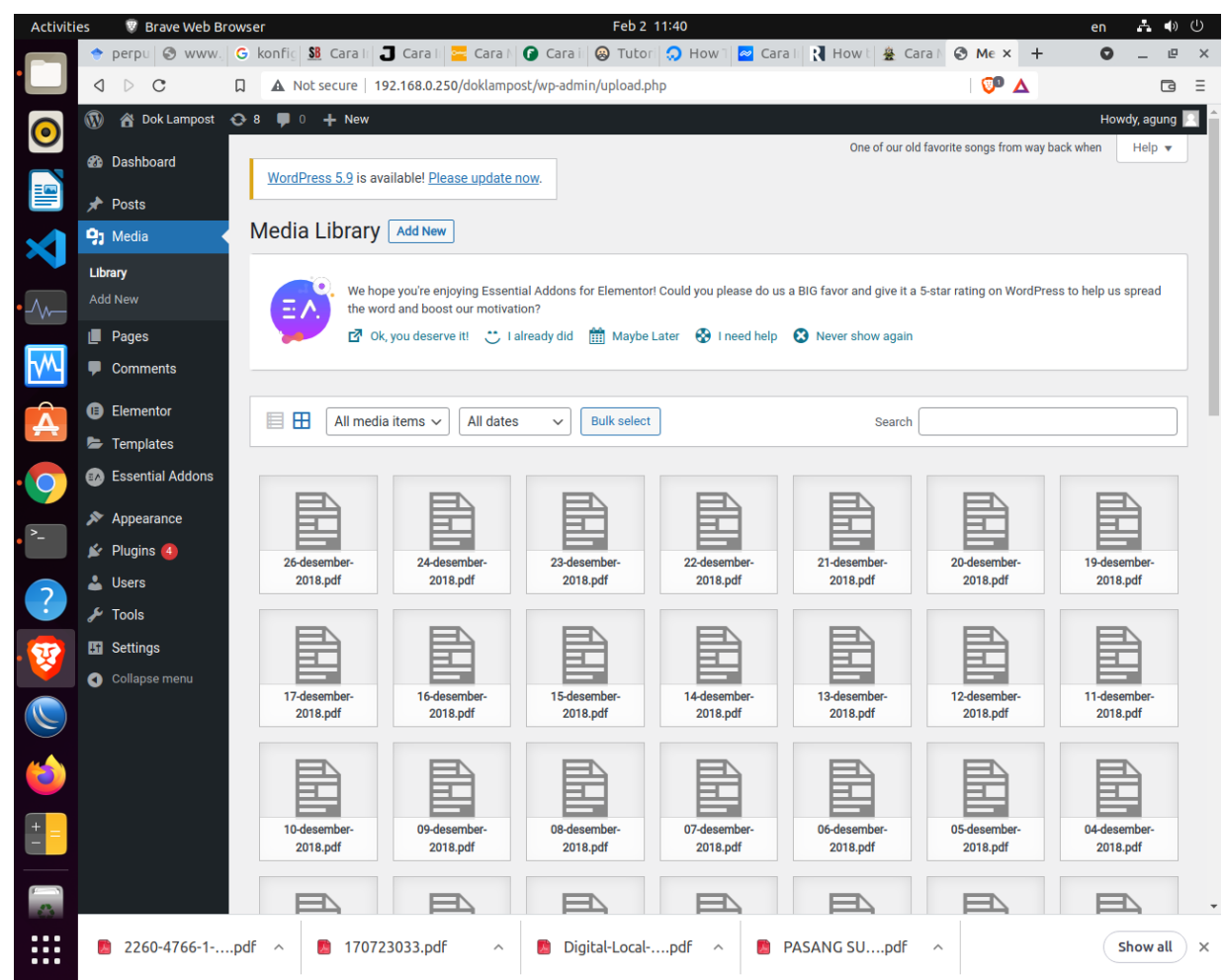

Gambar 5 Halaman Beranda Admin

Pada gambar 5 tersebut terlihat halaman admin di gunakan untuk pengolahan data, seperti input, upload dan delete data di dalam sistem repository, admin sendiri berfungsi banyak hal di dalam sistem tersebut. Pada gambar 6 terlihat dimana kumpulan atau repository e-pappers koran tersedia di halaman web tersebut, dan fungsinya dimana user melihat dan mencari data yang di butuhkan oleh user tersebut. 


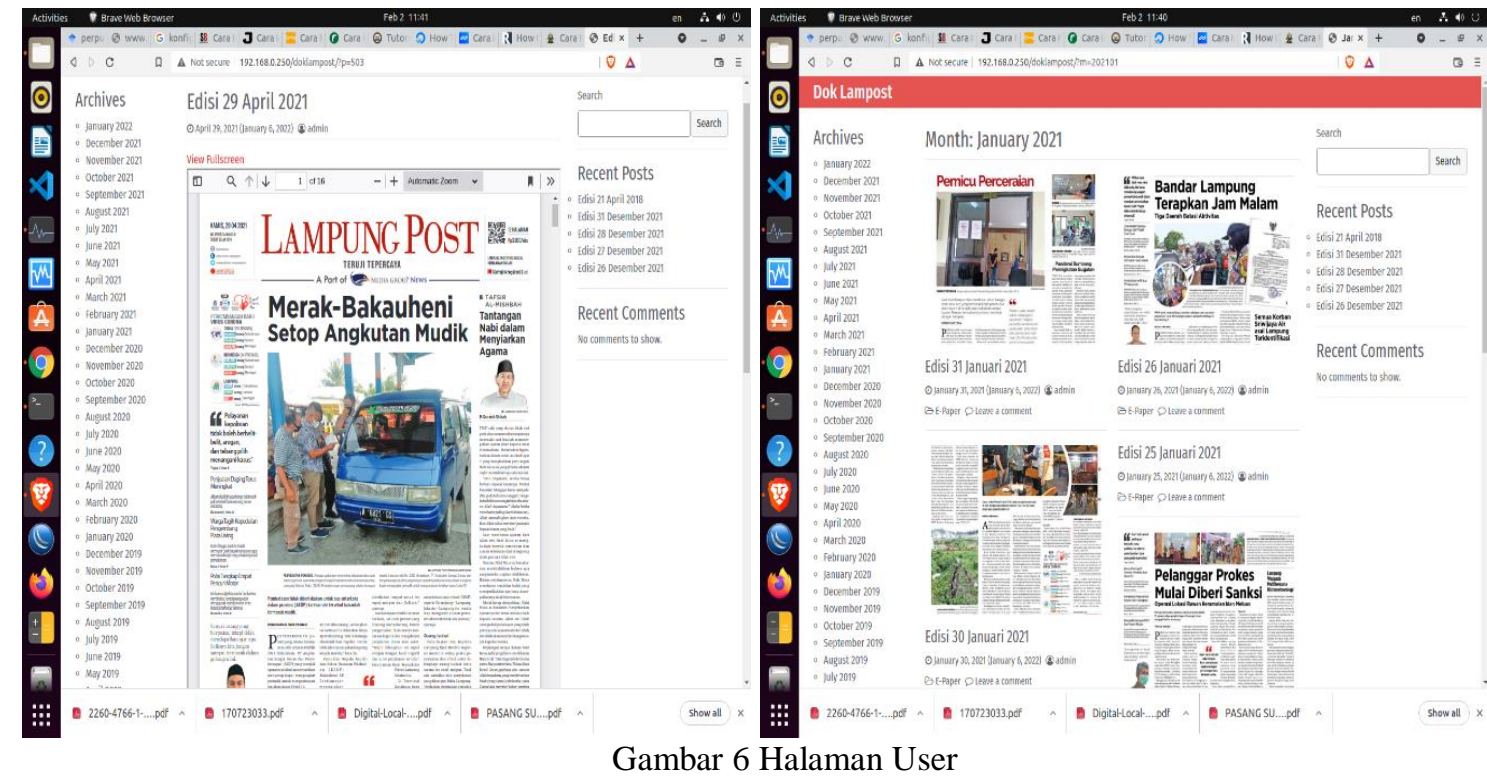

\section{Kesimpulan}

Hasil Penelitian dari Implementasi Sistem Repository E-papper Koran dapat disimpulkan antara lain :

1. Memudahakan pendokumentasian dan pencarian data oleh tiap user yang membutuhkan

2. Penghematan dalam pengoperasian sistem tersebut

\section{Daftar Pustaka}

[1] M. H. P. Jimi Ali Baba1, Ricco Herdiyan Saputra2, "ISSN 2798-3641 (Online)," IMPLEMENTASI Sist. Inf. IVENTARISASI Komput. PADA PT. MASA KINI MANDIRI, vol. 1, no. 6, p. 903, 2021.

[2] R. Kania, R. Effendi, and M. R. Sidik, "Sistem Repository Perpustakaan Pada Universitas Banten Jaya Berbasis Web (Studi Kasus : Universitas Banten Jaya),” J. Sist. Inf. dan Inform., vol. 4, no. 2, pp. 201214, 2021.

[3] Reni Nuraini Putri Habibi, "Manajemen redaksi," 2010.

[4] E. S. L. WIWIL, TINTIEN KOERNIAWATI, "Self-Evaluation Tool for Documenting Best Practices in," Acarya Pustaka, vol. 8, no. 1, 2021.

[5] M. Munawir, S. Susmanto, Z. Zulfan, and T. Hidayat, "Perancangan Aplikasi Pengelolaan Surat pada Dinas Kependudukan Catatan Sipil Kabupaten Aceh Besar," J. Serambi Eng., vol. 5, no. 3, 2020.

[6] Sutedjo, "Tujuan Repository Manfaat dan Fungsi Repository," Makal. di sampaiakan pada Semin. Nas. Digit. Local Content Strateg. Membangun Repos. Karya Seni., pp. 1-15, 2014.

[7] E. Erdiwansyah, M. Munawir, S. Susmanto, Z. Zulfan, and T. Hidayat, "Sistem Pendukung Keputusan Managemen BUMG Gampong Lambeugak Kecamatan Kuta Cot Glie Aceh Besar," BAKTIMAS J. Pengabdi. pada Masy., vol. 3, no. 3, pp. 93-100, 2021.

[8] M. Siregar, N. Kusumawati, Asmira, and Aris Susanto, "Sistem Informasi Company Profile PT. Sinar Nusantara Sakti Menggunakan Wordpress,” Simkom, vol. 6, no. 1, pp. 46-57, 2021.

[9] M. Munawir et al., "Penerapan Sistem Informasi Pendataan Penerima Dana Program Keluarga Harapan pada Gampong Beurawe Kecamatan Kuta Alam berbasis Web GIS,” J. Serambi Eng., vol. 6, no. 3, 2021.

[10] D. Anjarkusuma, B. Soepeno, J. A. Niaga, N. Malang, and D. A. C. Id, "Penggunaan Aplikasi CMS Wordpress Untuk Merancang Website Sebagai Media Promosi pada Maroon Wedding Malang," $J$. AKUNTANSI, Ekon. dan Manaj. BISNIS, vol. 2, no. 1, p. 63, 2014.

[11] P. Iksan, N. Nilma, and R. A. Sumarni, "Perancangan Sistem Administrasi Presensi dan Penggajian Pegawai di TK Annisa Cibinong," J. Nas. Komputasi dan Teknol. Inf., vol. 3, no. 3, pp. 281-287, 2020.

[12] A. Q. Novianto, "Repositori Institusi dan Kontribusinya dalam Meningkatkan Reputasi Universitas (Studi di UPT Perpustakaan Universitas Negeri Malang)," Bul. Perpust. Univ. Islam Indones., vol. 3, no. 2, pp. 95-116, 2020. 